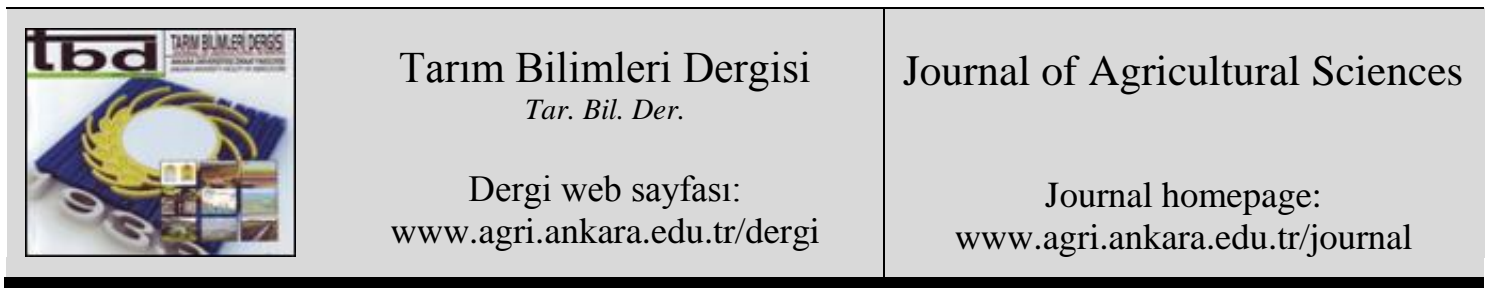

\title{
Comparison of Bread Wheat Genotypes for Leaf Rust Resistance Genes
}

\author{
İsmet BAŞER ${ }^{a}$, Behiye Banu BíLGEN ${ }^{b}$, Alpay BALKANa ${ }^{a}$, Zahit Kayıhan KORKUT ${ }^{a}$, Oğuz BíLGíN ${ }^{a}$, \\ Eylem GÜLFIDAN ${ }^{a}$

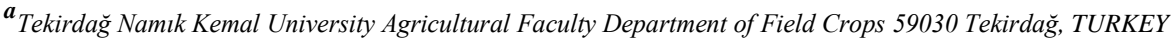

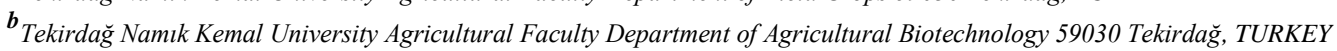

\section{ARTICLE INFO}

Research Article

Corresponding Author: İsmet BAŞER, E-mail: ibaser@nku.edu.tr, Tel: +90 (282) 2502002

Received: 25 July 2018, Received in Revised Form: 19 November 2018, Accepted: 21 November 2018

\section{AUTHORS ORCID ID}

(İsmet BAŞER: 0000-0001-6748-375), (Behiye Banu BİLGEN: 0000-0001-8323-2509), (Alpay BALKAN: 0000-0002-92036144), (Zahit Kayihan KORKUT: 0000-0002-2336-2791), (Oğuz BİLGİN: 0000-0002-4338-9912), (Eylem GÜLFIDAN: 0000-0002-2173-6354)

\begin{abstract}
Leaf rust caused by Pucinia recondita tritici is one of the most important diseases of bread wheat worldwide. It is considered that the most environmentally sound; low cost method of controlling leaf rust is to breed and grow genetically resistant wheat varieties. In the research, twentyfour bread wheat varieties grown intensively were used as genetic material in Trakya Region where the North-West Part of Turkey. To create artificial leaf rust epidemic in field conditions, two sensitive varieties (Morrocco and Cumhuriyet 75) was sown after each ten genotypes, and the reactions of the varieties to leaf rust were investigated in field conditions. Isogenic lines carrying the genes $\operatorname{Lr} 9, \operatorname{Lr} 14, \operatorname{Lr} 19$, $L r 24$ and $L r 47$ from CIMMYT were used as control genotypes in molecular analysis.
\end{abstract}

In the field conditions, although Pehlivan, Selimiye, Sagittario, Tina, Anapo, Montchill and Saraybosna were the most sensitive genotypes, Nota, Kate A1, Prostor and Sana were the most resistant bread wheat varieties to leaf rust. It was determined that Sana, Pehlivan, Golia, Falmura 85, Saroz 95, Renan, Sirena, Kate A1, Selimiye, Bezostoja 1, Saraybosna, Nina and Tina varieties have $\operatorname{Lr} 9$ gene with SSR analysis. It has been observed that all bread wheat varieties carry $L r 14, L r 19, L r 24$ and $L r 47$ (except Krasunia, Aldane and Gelibolu varieties) genes.

It is revealed that $\operatorname{Lr} 9$ and $\operatorname{Lr} 47$ genes should be taken into consideration in the studies to be performed in the region and these genes will be useful to examine together with a larger number of leaf rust genes for more successful results in breeding studies.

Keywords: Bread wheat; Leaf rust; SSR; STR; Molecular characterization

(C) Ankara Üniversitesi Ziraat Fakültesi

\section{Introduction}

Bread wheat (Triticum aestivum L.) was one of the earliest domesticated food crops and, for 8,000 years, is a basic nutrient of about $35 \%$ of the world's population, provides $20 \%$ of the calories from food of the major civilizations (CGIAR 2012). It can be said that the most important reasons for this are the richness of the variety, the widespread use of the industry and its wide adaptability. Undoubtedly, wheat will be among the first few products to meet this nutritional need. Despite the use of many methods to protect plants from damage caused by diseases, crop losses can reach very high levels. It is believed that product 
losses resulting from diseases are $12 \%$ of the total product in the world (Agrios 1997; Boyraz \& Delen 2005). Diseases not only reduce the quantity of the products but also the quality of the products.

As in the world, wheat is produced in a wider area than other cultivated plants in our country, and Trakya Region is one of the important wheat production regions. Abiotic and biotic stress factors in the region lead to quantitative and qualitative losses in different levels. The most important biotic stress factors in the Trakya region are leaf rust and the yield losses due to this disease changes depending on the severity of the disease and the susceptibility of the wheat genotypes. In other words, the severity or infection type of leaf rust is determined by the interaction between the resistance genes of the bread wheat genotype and the aggressive genes of the rust disease. The brown rust (10-75\%) and yellow rust (20-60\%) in wheat were reported to cause significant yield losses (Aktaş 2001). Leaf rust disease is the oldest disease known in wheat (Kolmer 2013) and causes significant loss of grain number and grain weight (Marasas et al 2004; Kolmer et al 2005; Huerta-Espino et al 2011; Draz et al 2015). It can cause product losses ranging from $2 \%$ to $90 \%$ worldwide (Bajwa et al 1986; Aktaş 2001; Singh et al 2004). The loss of crops is different according to the sensitivities of the varieties, the environmental conditions and the race of the disease

Few studies have been carried out on wheat varieties' resistance to rust diseases in Trakya region. The morphological and molecular identification of the leaf rust resistance is important in bread wheat varieties. When these features are revealed in genotypes, the experience and knowledge required for wheat breeding trials will be ensured and crop losses of producers will be reduced.

In many cases resistance genes can only be identified using molecular markers (Melchinger 1990). Over the last 15 years many efficient markers for leaf rust resistance genes have been described. The molecular markers most closely linked to $L r$ genes are based on the PCR technique, as the majority of these can be applied relatively easily in wheat breeding programmers (Imbaby et al 2014). SSR (Simple Sequence Repeat) is one of the PCR based DNA markers that provides determination of polymorphism in repeat motifs in a microsatellite locus (Jones et al 1997). SSR and other molecular markers have been used for determination of resistant genes for rust diseases (Gupta et al 2010). Seyfarth et al (2000) used the SSR markers in two different wheat populations to identify the $L r 13$ gene. Greganova et al (2003) investigated the Lr13 gene in Slovak winter wheat cultivars with SSR markers. In Blaszczyk et al (2005), Nearly Isogenic Lines (NIL) marker are used as materials for the first time for Lr13 gene. Polymorphism determined at the DNA level between two close isogenic lines was found to be very likely to be in a linkage with the target gene (Masojc 2002). Thatcher isogenic lines are very useful in detecting pathogen virulent combinations as well as in identifying resistance genes (Winzeler et al 2000).

In recent years, the use of leaf rust resistant genes in winter wheat breeding has reduced the losses caused by leaf rust. But, there are many races of leaf rust and varieties are not resistant to all races. Every few years, new disease races are observed and durable varieties can be sensitive. The duration of a leaf rust resistance of wheat varieties can vary from 2 to 4 years. Wheat breeding programs should be continued by transferring new resistance genes to new varieties (Lipps 2006). This disease is widespread in our country, especially Trakya, in all coastal regions like Aegean, Marmara and Black Sea (Altay 1980). The diseases resistance is provided by the durability in the adult plant period (McIntosh et al 1995; Seyfarth et al 2000).

Disease damage is seen in different levels every year in the Trakya region. Despite the intense chemical application for rust diseases, the product losses caused by the diseases increase every year. One of the most effective and accepted approaches to prevent disease is the development of cultivars resistance. If the brown basal reactions of common wheat genotypes can be determined, resistant genotypes can be used as a source of resistance in the breeding programs. Thus, the effectiveness of breeding programs can be improved by selecting appropriate parents. In addition, the use of resistant genotypes will provide significant contributions to both the region and the country's economy.

The aim of this study was to identify $L r$ resistance genes present in a collection of bread wheat cultivars grown in Trakya Region where the North-West Part of Turkey and to determine the level of adult plant resistance to leaf rust in these cultivars.

Tarım Bilimleri Dergisi - Journal of Agricultural Sciences 26 (2020) 22-31 


\section{Material and Methods}

\subsection{Material}

The study was carried out in the Department of Field Crops, Agricultural Faculty, Tekirdağ Namık Kemal University during 2015 growing period. 24 bread wheat varieties were used genetic material (Table 1). The isogenic lines RL6010, RL6013, RL6009, and RL6010 from the CIMMTY were used to determine whether the $\operatorname{Lr} 9, \operatorname{Lr} 14$ a, $\operatorname{Lr} 19, \operatorname{Lr} 24$ and $\operatorname{Lr} 47$ genes were present in the wheat genotypes.

Table 1- Wheat genotypes tested for leaf rust resistance

\begin{tabular}{|c|c|}
\hline \multicolumn{2}{|c|}{ Genotypes and their abbreviations } \\
\hline Kate A-1 (Ka) & Esperia (Es) \\
\hline Pehlivan (Pe) & Sagittaria (Sag) \\
\hline Prostor $(\operatorname{Pr})$ & Krasunia (Kr) \\
\hline Saroz 95 (Sar) & Sirena $(\mathrm{Si})$ \\
\hline Selimiye (Se) & Anapo (An) \\
\hline Saraybosna (Sa) & Bereket $(\mathrm{Be})$ \\
\hline Gelibolu (Ge) & Falmura $85(\mathrm{Fa})$ \\
\hline Tekirdağ (Te) & Nota $(\mathrm{No})$ \\
\hline Bezostoja $1(\mathrm{Be})$ & Golia (Go) \\
\hline Pamukova $97(\mathrm{~Pa})$ & Sana (San) \\
\hline Montchill (Mo) & Tina $(\mathrm{Ti})$ \\
\hline Rumeli (Ru) & Nina $(\mathrm{Ni})$ \\
\hline
\end{tabular}

\subsection{Methods}

Adult plant resistance to leaf rust was investigated on the experimental area of Department of Field Crops, Agricultural Faculty, Tekirdağ Namık Kemal University. The resistance to leaf rust disease provides resistance in the adult plant period (McIntosh et al 1995; Seyfarth et al 2000). Seeds of all bread wheat genotypes were sown in November 11, 2015. The tested varieties were sown in experimental units (plots) containing three rows with $6 \mathrm{~m}$ long and $20 \mathrm{~cm}$ with 500 seeds per square meter. The experiment was designed in a complete randomized block design with three replicates. Two sensitive genotypes were sown after each ten genotypes. Morocco bread wheat variety which is sensitive to leaf rust was sown around the parcels. All cultural practices such as fertilization, irrigation and other management were applied according to standard procedures in the region. In the study, the variance analysis for decare grain yield was analyzed according to the randomized block design. In order to determine the difference between genotypes, Duncan test was applied.

\subsubsection{Disease observations}

When rust symptoms were fully developed nearly at the early dough stage (Large 1954), the leaf rust data of adult plant reaction were scored as plant response and rust severity are combined together. Plant response was expressed in five infection types according to Johnston \& Browder (1966) i.e. Immune (0), no uredia or other macroscopic sign of infection, Resistant (R), small uredia surrounded by necrosis, Moderately Resistant (MR), small to medium uredia surrounded by chlorosis or necrosis, Moderately Susceptible (MS), medium-sized uredia that may be associated with chlorosis and Susceptible (S), large uredia without chlorosis or necrosis. Rust severity was expressed as percentage coverage of leaves with rust pustules following Cobb's scale modified by Peterson et al (1948).

\subsubsection{DNA isolation}

For the DNA isolation, the fresh leaves belonging to individuals of each genotype were used. Each sample was ground with a ball mill (Retsch ${ }^{\circledR}$ MM400). Total genomic DNA was isolated by using modified CTAB 
method (Doyle \& Doyle 1990). The DNA in samples was quantified with Qubit ${ }^{\circledR} 2.0$ Fluorometer and also controlled by electrophoresis on 1\% agarose gels with RedSafe Nucleic Acid Staining Solution in 1X TBE buffer at $80 \mathrm{~V}$ constant in 30 minute and visualized under UV light (Gel Imaging System Vilber Lourmat Quantum ST5). The extracted DNA samples was diluted to $25 \mathrm{ng} \mu \mathrm{L}^{-1}$ for PCR analysis and stored at - 20 ${ }^{\circ} \mathrm{C}$ for further use.

\subsubsection{Molecular marker analysis}

Five primers were used in the analysis of five different leaf rust resistance genes. The characteristics of the used primers are shown in Table 2.

Table 2- Characteristics of the markers used in the leaf rust resistance genes

\begin{tabular}{|c|c|c|c|c|}
\hline Lr Gene & Primer name & $5^{\prime} \rightarrow 3^{\prime}$ primer sequences & $\begin{array}{l}\text { Product size } \\
\text { (bp) }\end{array}$ & Reference \\
\hline Lr9 & $\begin{array}{l}\mathrm{J} 13 / 1 \\
\mathrm{~J} 13 / 2\end{array}$ & $\begin{array}{l}\text { TCCTTTTATTCCGCACGCCGG } \\
\text { CCACATACCCCAAAGAGACG }\end{array}$ & 1110 & Schachermayr et al (1994) \\
\hline Lr14a & $\begin{array}{l}\text { Xgwm146-F } \\
\text { Xgwm146-R }\end{array}$ & $\begin{array}{l}\text { CCAAAAAAACTGCCTGCATG } \\
\text { CTCTGGCATTGCTCCTTGG }\end{array}$ & 174 & Röder et al (1998) \\
\hline Lr19 & $\begin{array}{l}\mathrm{GbF} \\
\mathrm{GbR}\end{array}$ & $\begin{array}{l}\text { CATCCTTGGGGACCTC } \\
\text { CCAGCTCGCATACATCCA }\end{array}$ & 130 & Prins et al (2001) \\
\hline Lr24 & $\begin{array}{l}\mathrm{J} 09 / 1 \\
\mathrm{~J} 09 / 2\end{array}$ & $\begin{array}{l}\text { TCTAGTCTGTACATGGGGGC } \\
\text { TGGCACATGAACTCCATACG }\end{array}$ & 350 & Schachermayr et al (1994) \\
\hline Lr47 & $\begin{array}{l}\text { PS10L } \\
\text { PS10L2 }\end{array}$ & $\begin{array}{l}\text { TCTTCATGCCCGGTCGGGT } \\
\text { GGGCAGGCGTTTATTCCAG }\end{array}$ & 224 & Helguera et al (2000) \\
\hline
\end{tabular}

Molecular marker analysis was performed at the experimental field area and laboratories of Department of Field Crops and Department of Agricultural Biotechnology, Agricultural Faculty, University of Tekirdağ Namık Kemal. The DNA amplifications were carried out by using the Applied Biosystems ${ }^{\circledR}$ Veriti ${ }^{\circledR}$ Thermal Cycler, Applied Biosystems ${ }^{\circledR}$ ProFlex ${ }^{\mathrm{TM}}$ PCR System Thermal Cycler, with the following PCR profile shown in Table 3.

Table 3- Amplification parameters for all studied primer pairs

\begin{tabular}{|c|c|}
\hline & PCR cycle condition \\
\hline $\begin{array}{l}\mathrm{J} 13 / 1 \\
\mathrm{~J} 13 / 2\end{array}$ & $95^{\circ} \mathrm{C}$ for 5 min., 35 cycles of $\left(95^{\circ} \mathrm{C} 1\right.$ min., $62^{\circ} \mathrm{C} 1$ min., $\left.72^{\circ} \mathrm{C} 1 \mathrm{~min}.\right), 72^{\circ} \mathrm{C} 10 \mathrm{~min}$ \\
\hline $\begin{array}{l}\text { Xgwm146-F } \\
\text { Xgwm146-R }\end{array}$ & $95^{\circ} \mathrm{C}$ for 5 min., 35 cycles of $\left(95^{\circ} \mathrm{C} 1 \mathrm{~min} ., 56^{\circ} \mathrm{C} 1 \mathrm{~min} ., 72^{\circ} \mathrm{C} 1 \mathrm{~min}.\right), 72{ }^{\circ} \mathrm{C} 10 \mathrm{~min}$ \\
\hline $\begin{array}{l}\mathrm{GbF} \\
\mathrm{GbR}\end{array}$ & $95^{\circ} \mathrm{C}$ for 5 min., 35 cycles of $\left(95^{\circ} \mathrm{C} 1 \mathrm{~min} ., 56^{\circ} \mathrm{C} 1 \mathrm{~min} ., 72^{\circ} \mathrm{C} 1 \mathrm{~min}.\right), 72^{\circ} \mathrm{C} 10 \mathrm{~min}$ \\
\hline $\begin{array}{l}\mathrm{J} 09 / 1 \\
\mathrm{~J} 09 / 2\end{array}$ & $95^{\circ} \mathrm{C}$ for 5 min., 35 cycles of $\left(95^{\circ} \mathrm{C} 1 \mathrm{~min} ., 56^{\circ} \mathrm{C} 1 \mathrm{~min} ., 72^{\circ} \mathrm{C} 1 \mathrm{~min}.\right), 72^{\circ} \mathrm{C} 10 \mathrm{~min}$ \\
\hline $\begin{array}{l}\text { PS10L } \\
\text { PS10L2 }\end{array}$ & $95^{\circ} \mathrm{C}$ for 5 min., 35 cycles of $\left(95^{\circ} \mathrm{C} 1 \mathrm{~min} ., 62^{\circ} \mathrm{C} 1 \mathrm{~min} ., 72^{\circ} \mathrm{C} 1 \mathrm{~min}.\right), 72{ }^{\circ} \mathrm{C} 10 \mathrm{~min}$ \\
\hline
\end{tabular}

The volume of the reaction mixture was $10 \mu \mathrm{L}$, containing $1 \mathrm{X}$ reaction buffer, $2.5 \mathrm{mM} \mathrm{MgCl}$, dNTPs (each $0.2 \mathrm{mM}$ ), $0.5 \mu \mathrm{M}$ of each primer and 1.5 $\mathrm{U}$ of Taq polymerase. The template for PCR amplification consisted of $50 \mathrm{ng}$ of genomic DNA. PCR products were visualized on 1.7\% agarose gels with RedSafe Nucleic Acid Staining Solution in 1X TBE buffer and using a $100 \mathrm{bp}$ DNA ladder at $80 \mathrm{~V}$ constant in 1 
hour and visualized under UV light (Gel Imaging System Vilber Lourmat Quantum ST5) to determine the size of amplified fragments.

\section{Results and Discussion}

The cultivated wheat varieties have suffered from sudden epidemics during the last decades from the perspective of change in weather conditions in relation to the genetic makeup of both host and parasite. Currently, intensive chemical spraying is applied to wheat production areas against rust diseases. In Turkey, several genes, including leaf rust-resistant as $\operatorname{Lr} 9, \operatorname{Lr} 19, \operatorname{Lr} 24$ and $\operatorname{Lr} 28$, have been found to induce disease resistance.

\subsection{Disease evaluation}

Observations on leaf rust resistance levels of bread wheat varieties under field conditions indicate that the varieties show different responses to leaf rust (Table 4). The Nota with 5 MR value, and Kate A1, Prostor and Sana varieties with 10 MR values showed the highest resistance. Flamura 85, Golia, Krasunia, Rumeli, Pamukova and Tekirdağ varieties were followed by these varieties with $20 \mathrm{MS}$ value. The most sensitive genotypes for leaf rust among the 24 wheat genotypes was determined in Pehlivan and Bereket varieties with values of $40 \mathrm{~S}$ value. Bread wheat varieties Selimiye and Sagittario have followed these varieties with 40 MS values. Montchill with 30 MS value, Saraybosna, Saroz 95, Sirena, Anapo and Tina varieties with 20 MS value were later ranked. Bereket and Pehlivan bread wheat varieties which were observed the highest leaf rust values gave the lowest grain yields. The other wheat varieties with high leaf rust values were also in the lower order of grain yield. The highest grain yield was obtained from Rumeli, Krasunia, Tekirdağ and Tina (MR) genotypes.

Table 4- Leaf rust values in bread wheat varieties

\begin{tabular}{lcl}
\hline Varieties & Leaf rust values & $\begin{array}{l}\text { Grain yield } \\
\left(\mathrm{kg} \mathrm{da}^{-1}\right)\end{array}$ \\
\hline Kate A-1 & $10 \mathrm{MR}$ & $646.667 \mathrm{~cd}$ \\
Pehlivan & $40 \mathrm{~S}$ & $538.000 \mathrm{fgh}$ \\
Prostor & $10 \mathrm{MR}$ & $457.667 \mathrm{k}$ \\
Saroz 95 & $20 \mathrm{MS}$ & $568.667 \mathrm{ef}$ \\
Selimiye & $40 \mathrm{MS}$ & $608.000 \mathrm{de}$ \\
Saraybosna & $20 \mathrm{MS}$ & $515.667 \mathrm{ghi}$ \\
Gelibolu & $30 \mathrm{MR}$ & $481.333 \mathrm{ik}$ \\
Tekirdag & $20 \mathrm{MR}$ & $691.333 \mathrm{abc}$ \\
Bezostoja 1 & $30 \mathrm{MR}$ & $502.667 \mathrm{ghi}$ \\
Pamukova 97 & $20 \mathrm{MR}$ & $358.000 \mathrm{l}$ \\
Montchill & $30 \mathrm{MS}$ & $663.667 \mathrm{bc}$ \\
Rumeli & $20 \mathrm{MR}$ & $742.333 \mathrm{a}$ \\
Esperia & $40 \mathrm{MR}$ & $657.000 \mathrm{bc}$ \\
Sagittaria & $40 \mathrm{MS}$ & $503.667 \mathrm{hik}$ \\
Krasunia & $20 \mathrm{MR}$ & $699.667 \mathrm{ab}$ \\
Sirena & $20 \mathrm{MS}$ & $544.667 \mathrm{fg}$ \\
Anapo & $20 \mathrm{MS}$ & $602.667 \mathrm{e}$ \\
Bereket & $40 \mathrm{~S}$ & $378.667 \mathrm{l}$ \\
Falmura 85 & $20 \mathrm{MR}$ & $560.667 \mathrm{ef}$ \\
Nota & $5 \mathrm{MR}$ & $577.667 \mathrm{ef}$ \\
Golia & $20 \mathrm{MR}$ & $461.667 \mathrm{k}$ \\
Sana & $10 \mathrm{MR}$ & $492.333 \mathrm{ik}$ \\
Tina & $20 \mathrm{MR}$ & $734.000 \mathrm{a}$ \\
Nina & $40 \mathrm{MR}$ & $731.333 \mathrm{a}$ \\
HKO & & 616.894 \\
\hline
\end{tabular}

\subsection{Molecular evaluation}

Isogenic lines carrying the $L r$ genes provided in CIMMTY (Mexico) were used as materials to determine whether the 24 wheat cultivars carry the $\operatorname{Lr} 9, \operatorname{Lr} 14, \operatorname{Lr} 19, \operatorname{Lr} 24$, and $\operatorname{Lr} 47$ genes. The data obtained using 5 
different molecular markers (SSR primers) were given in Table 5 and Figure 1.

Assessment among varieties based on the results of molecular marker analysis, it has been determined that Esperia, Sagittario, Rumeli, Prostor, Golia, Bereket, Montchill, Aldane, Pamuova, Tekirdağ and Krasunia bread wheat varieties carry the $\operatorname{Lr} 9$ gene, the other 13 bread wheat varieties do not carry this gene. Although all bread wheat varieties possess the $L r 19, L r 14$ a and $L r 24$ genes, 21 bread wheat varieties of them possess Lr47 gene. Only Krasunia, Golia and Aldane bread wheat varieties do not carry the $\operatorname{Lr} 47$ gene. Bread wheat varieties Nota, Sana, Prostor showed the most resistant to leaf rust in the field conditions. Then, Tekirdağ, Pamukova 9, Rumeli, Krasunia, Flamura 85, Golia and Tina varieties were also most resistant other varieties. The most sensitive varieties in terms of leaf rust resistance were Pehlivan, Bereket, Selimiye Sagittario and Montchill varieties, and Saraybosna, Sirena Anapo and Tina varieties were followed them.

Table 5- Presence of $\mathrm{Lr}$ resistance genes in the wheat genotypes $[(+)$ presence ofgene, $(-)$ absence of gene $]$

\begin{tabular}{lccccc}
\hline Genotypes & Lr9 & Lrl4a & Lrl9 & Lr24 & Lr 47 \\
\hline Sana & + & + & + & + & + \\
Pehlivan & + & + & + & + & + \\
Golia & + & + & + & + & + \\
F-85 & + & + & + & + & + \\
Krasunia & - & + & + & + & - \\
Saroz-95 & + & + & + & + & + \\
Aldane & - & + & + & + & - \\
Pamukova & - & + & + & + & + \\
Tekirdag & - & + & + & + & + \\
Montchill & - & + & + & + & + \\
Renan & + & + & + & + & + \\
Syrena & + & + & + & + & + \\
Kate A-1 & + & + & + & + & + \\
Selimiye & + & + & + & + & + \\
Bezostaja 1 & + & + & + & + & + \\
Saraybosna & + & + & + & + & + \\
Nina & + & + & + & + & + \\
Gelibolu & - & + & + & + & - \\
Bereket & - & + & + & + & + \\
Tina & + & + & + & + & + \\
Esperia & - & + & + & + & + \\
Sagittario & - & + & + & + & + \\
Rumeli & - & + & + & + & + \\
Prostor & - & + & + & + & + \\
Positive control & + & + & + & + & + \\
\hline & & & & &
\end{tabular}

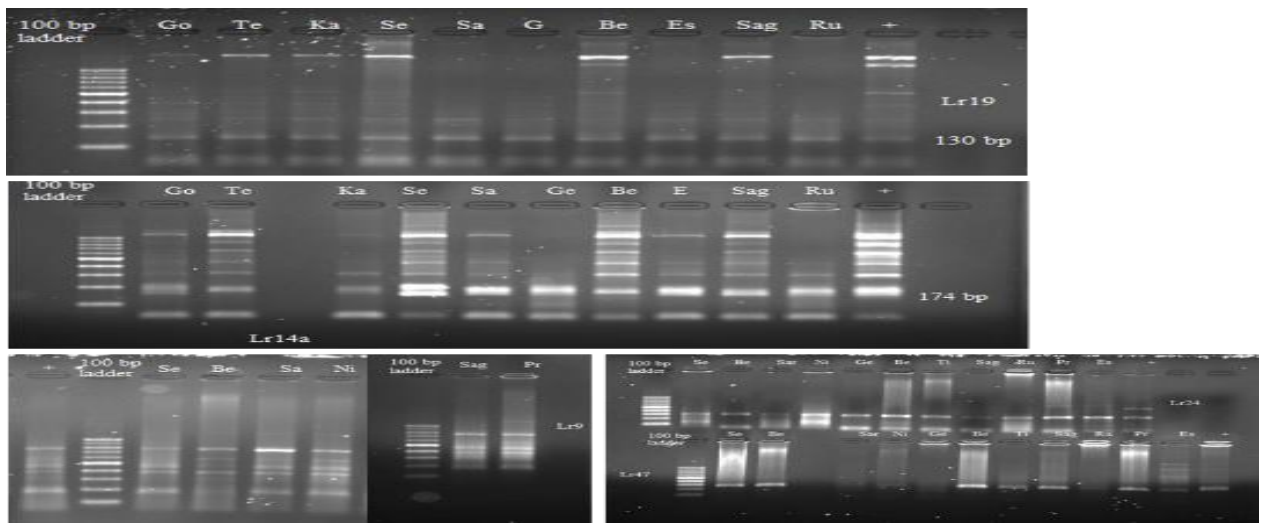

Figure 1- PCR amplification of some genotypes for A) Lr19 B) Lr14 c)..... genes using specific molecular markers

Tarım Bilimleri Dergisi - Journal of Agricultural Sciences 26 (2020) 22-31 


\section{Conclusions}

The detection of resistant genotypes with more stable and easier molecular markers replaced the older methods such as inoculation by pathogens or more complicated markers with poor repeatability. Various marker types are available for marker assisted selection of resistant genotypes for leaf rust such as ISSR, SCAR, AFLP, STS and SSR (Gold et al 1999; Prins et al 2001; Gupta et al 2006; Li et al 2010; Zhang et al 2011; Zhou et al 2012; Zhou et al 2013). According to the results obtained in uncontrolled conditions, the bread wheat genotypes were affected at different levels of leaf rust. While Pehlivan, Gelibolu, Bereket and Pamukova and Golia varieties which are sensitive to leaf rust were located in the lower ranks due to yielding grain, Nina, Tina, Krasunia, Rumeli and Tekirdağ varieties which are more resistant to leaf rust have higher values in terms of grain yield. The obtained data do not show that selection may be successful for rust disease in field conditions.

In this study, the molecular genetic markers of $\operatorname{Lr} 9, \operatorname{Lr} 14, \operatorname{Lr} 19, \operatorname{Lr} 24$, and $\operatorname{Lr} 47$ in bread wheat cultivars were used to identify the 23 wheat cultivars. Esperia, Sagittario, Rumeli, Prostor, Gelibolu, Bereket, Montchill, Aldane, Pamuova, Tekirdag and Krasunia did not carry the $\operatorname{Lr} 9$ gene and the remaining 13 bread wheat genotypes carried the $L r 9$ gene. $L r 14$ a, $L r 19$ and $L r 24$ genes were found in all of the 24 tested bread wheat cultivars. Tonk \& Yüce (2007) studied SSR markers for Lr13 gene in 41 Thatcher near isogenic lines, they reported that the $\mathrm{F}_{1}$ individuals (İzmir $85 \mathrm{x}$ resistant near isogenic line) might have $\operatorname{Lr} 13$ gene. Kolmer et al (2012) studied various varieties in Samsun, İzmir and Sakarya at 2009-2011 and reported presence of $L r 34$ in 2 varieties, $L r 37$ in 3 varieties. Khurana et al (2004), $L r 1, L r 3, L r 10, L r 13, L r 23$ and Lr26 gene was reported in 37 wheat lines from Turkey. Studies by different researchers with different materials in different years and areas have shown that leaf rust is different in terms of resistance genes (Moldovan et al 2004; Xu et al 2005; Elyasi-Gomari \& Lesovaya 2009; Huerta-Espino et al 2011; Gorash et al 2014; Zaman et al 2017).

Imbaby et al (2014) studied $L r$ genes in fifteen wheat cultivars from Egypt. They reported ten genes, Lr13, Lr19, Lr24, Lr26, Lr34, Lr35 Lr36, Lr37, Lr39, and Lr46, in fifteen wheat cultivars using various molecular markers. $L r 13, L r 24, L r 34$, and $L r 36$ genes were the most frequently occurred in fifteen Egyptian wheat cultivars (100\%). The percentage of other genes were as Lr26 and Lr35 (93\%), Lr39 (66\%), Lr37 (53\%), Lr19 (33.3\%) and Lr46 (26.6\%). Wang et al (2014) reported that wheat line 5R618, $\mathrm{F}_{2}$ plants and $\mathrm{F}_{2: 3}$ families from a cross between 5R618 and Zhengzhou5389 (susceptible) may contain $\operatorname{Lr} 9, \operatorname{Lr} 24, \operatorname{Lr} 19$, Lr28, Lr39, Lr42, Lr47, Lr51, and Lr53 genes using molecular markers. Vanzetti et al (2011) studied 66 wheat cultivars from Argentina to identify $L r$ genes that condition leaf rust resistance. Vanzetti et al (2011) determined presence of $\operatorname{Lr} 9, \operatorname{Lr} 10, \operatorname{Lr} 1$ 9, Lr20, Lr21, Lr24, Lr25, Lr26, Lr29, Lr34, Lr35, Lr37, Lr47 and $L r 51$ by molecular markers. They conclude that combinations including seedling resistance genes like $\operatorname{Lr} 16$, Lr47, Lr19, Lr41, Lr21, Lr25 and Lr29, with adult plant resistance genes like Lr34, SV2 and Lr46 might provide durable and effective resistance to leaf rust in their studied region. According to the obtained data in our study, it is seen that there are some deviations in molecular and morphological data on leaf rust. This suggests that especially morphological studies should be done for a few years. It is revealed that $L r 9$ gene and $L r 47$ genes should be taken into consideration in the studies to be performed in the region, and also it would be useful to examine a larger number of leaf rust genes for successful results in plant breeding.

Marker assisted selection (MAS) studies which researchers or breeders use special molecular markers linked to $L r$ genes, provides the pyramiding of several effective resistance genes. Detection of resistance genes via molecular markers is easy, cheap and time effective way to detect resistance in wheat varieties of unknown parentage. According to our results, in order to design crossing program for breeding strategies obtained information from MAS might be used.

\section{Acknowledgements}

This work was supported by Tekirdağ Namık Kemal University, Scientific Research Projects Unit (Project No. NKUBAP.00.24.AR.14.01). 


\section{References}

Agrios G N (1997). Plant Pathology, Fourth Edition ed., Academic Press, San Diego, pp. 635

Aktaş H (2001). Önemli hububat hastalıkları ve survey yöntemleri. Tarım ve Köyişleri Bakanlığı. Bitki Sağlığı Araştırmaları Daire Başkanlığı, Ankara, $74 \mathrm{~s}$

Altay F (1980). Kahverengi pasa mukavemet kaynakları ve 1slahı. Bitki Islahı Sempozyumu, 22-25 Mayıs 1979, Menemen-İzmir, Ege Tarımsal Araştırma Enstitüsü Yayınları, No: 17/41, s. 217-240

Bajwa M A, Aqil K A \& Khan N I (1986). Effect of leaf rust on yield and kernel weight of spring wheat. RACHIS 5: $25-28$

Blaszczyk L, Tyrka M \& Chelkowski J (2005). Pst1AFLP based markers for leaf rust resistance genes in common wheat. Journal Applied Genetics 46(4): 357-364

Boyraz N \& Delen S (2005). Bitkilerin hastalıklara karşı dayanıklılığında konukçu enzimlerin rolü. S.Ü. Ziraat Fakültesi Dergisi 19(35): 51-59

CGIAR (2013). Wheat 2012 annual report. Agricultural research for development improves food security, CIMMYT, Mexico, pp. 32

Doyle J J \& Doyle J L (1990). Isolation of plant DNA from fresh tissue. Focus 12: 13-15

Draz I S, Abou-Elseoud M S, Kamara A M, Alaa-Eldein O A \& El-Bebany A F (2015). Screening of wheat genotypes for leaf rust resistance along with grain yield. Annals of Agricultural Sciences 60(1): 29-39

Elyasi-Gomari S \& Lesovaya G M (2009). Harmfulness of wheat leaf rust in the eastern part of forest-steppe of Ukraine. Archives of Phytopathology and Plant Protection 42: 659-665

Gold J, Harder D, Townley-Smith F, Aung T \& Procunier J (1999). Development of a molecular marker for rust resistance genes Sr39 and Lr35 in wheat breeding lines. Electronic Journal of Biotechnology 2: 1-2

Gorash A, Galaev A, Babayants O \& Babayants L (2014). Leaf rust resistance of bread wheat (Triticum aestivum L.) lines derived from interspecific crosses. Zemdirbyste-Agriculture 101(3): 295-302

Greganova Z, Kraic J \& Galova Z (2003). Diagnostic of wheat leaf rust resistance genes by DNA application in MAS. Czech Journal of Genetics and Plant Breeding 39(4): 127-129

Gupta P K, Landridge P \& Mir R R (2010). Marker-assisted wheat breeding: present status and future possibilities. Molecular Breeding 26: 145-161

Gupta S K, Charpe A, Koul S, Haque Q \& Prabhu K (2006). Development and validation of SCAR markers cosegregating with an Agropyron elongatum derived leaf rust resistance gene Lr24 in wheat. Euphytica 150: 233-240

Helguera M, Khan I A \& Dubcovsky J (2000). Development of PCR markers for the wheat leaf rust resistance gene Lr47. Theoretical and Applied Genetics 100: 1137-1143

Huerta-Espino J, Singh R P, German S, McCallum B D, Park R F \& Chen W Q (2011). Global status of wheat leaf rust caused by $P$. triticina. Euphytica 179: 143-160

Imbaby I A, Mahmoud M A, Hassan M E M \& Abd-El-Aziz A R M (2014). Identification of leaf rust resistance genes in selected egyptian wheat cultivars by molecular markers. The Scientific World Journal pp. 1-7

Johnston C O \& Browder L E (1966). Seventh revision of the international register of physiologic races of Puccinia recondita f. sp. tritici. Plant Disease Report 50: 756-760

Jones N, Ougham H \& Thomas H (1997). Markers and mapping: We are all geneticists now. New Phytologist 137: $165-177$

Tarım Bilimleri Dergisi - Journal of Agricultural Sciences 26 (2020) 22-31 
Khurana R, Nayar S K \& Lakhanpal T N (2004). Brown rust resistance in wheat lines from Turkey. Plant Disease Research (Ludhiana) 19: 20-24

Kolmer J A (2013). Leaf rust of wheat: Pathogen biology, variation and host resistance. Forests 4: 70-84

Kolmer J A, Long D L \& Hughes M E (2005). Physiological specialization of Puccinia triticina on wheat in the United States in 2003. Plant Disease 89: 1201-1206

Kolmer J A, Hanzalova A, Goyeau H, Bayles R \& Morgounov A (2012). Genetic differentiation of the wheat leaf rust fungusPuccinia triticinain Europe. Plant Pathology: 1-11

Large E C (1954). Growth stages in cereals. Illustration of the Feekes scale. Plant Pathology 3: 128-129

Li X, Li Z F, Li Y N, Zhao Z Q, Liu D Q, Wang C F, Gao L J \& Sun D J (2010). Genetic analysis and molecular mapping of leaf rust resistance gene in wheat line Xinong 1163-4. Scientia Agricultura Sinica 43: 2397-2402

Lipps P E (2006). Ohio State University, Extension Fact Sheet, Plant Pathology, http://ohioline.osu.edu./acfact/0006.html

Marasas C N, Smale M \& Singh R P (2004). The Economic impact in developing countries of leaf rust resistance breeding in CIMMYT-related spring bread wheat. International Maize and Wheat Improvement Center, Mexico, DF, pp. 33

Masojc P (2002). The application of molecular markers in the process of selection. Cellular \& Molecular Biology Letters 7: 499-509

McIntosh R A, Wellings C R \& Park R F (1995). Wheat rusts: An atlas of resistance genes. Kluwer Academic Publishers, Dordrecht

Melchinger A E (1990). Use of molecular markers in breeding for oligogenic disease resistance. Plant Breeding 104: $1-19$

Moldovan M, Moldovan V \& Kadar R (2004). Characterization of wheat rust and powdery mildew populations in Transylvania and implications in breeding for resistance. Romanian Agricultural Research 21: 1-11

Peterson R F, Campbell A B \& Hannah A E (1948). A diagrammatic scale for estimating rust intensity on leaves and stems of cereals. Canadian Journal Research 60: 496-500

Prins R, Groenewald J Z, Marais G F., Snape J W \& Koebner R M D (2001). AFLP and STS tagging of Lr19, a gene conferring resistance to leaf rust in wheat. Theoretical and Applied Genetics 103: 618-624

Röder M S, Korzun V, Wendehake K, Plaschke J, Tixier M-H, Leroy P \& Ganal M (1998). A microsatellite map of wheat. Genetics 149: 2007-2023

Seyfarth R, Feuillet C, Schachermayr G, Messmer M, Winzeler M \& Keller B (2000). Molecular mapping of the adultplant leaf rust resistance gene Lr13 in wheat (Triticum aestivum L.). Journal of Genetics Breeding 54: 193-198

Singh R P, Huerta-Espino J, Pfeiffer W \& Figueroa-Lopez P (2004). Occurrence and impact of a new leaf rust race on durum wheat in northwestern Mexico from 2001 to 2003. Plant Disease 88: 703-708

Tonk F A \& Yüce S (2007). Ekmeklik buğday İzmir 85 çeşidinde ve Thatcher yakın izogenik hatlarında kahverengi pas dayanıkl11ık geni Lr13'ün SSR markörleriyle incelenmesi. Ege Üniversitesi Ziraat Fakültesi Dergisi 44: 13-25

Vanzetti L S, Campos P, Demichelis M, Lombardo L A, Aurelia P R, Vaschetto L M, Bainotti C T \& Helguera M (2011). Identification of leaf rust resistance genes in selected Argentinean bread wheat cultivars by gene postulation and molecular markers. Electronic Journal of Biotechnology 14(3): 1-17

Wang J, Shi L, Zhu L, Li X \& Liu D (2014). Genetic analysis and molecular mapping of leaf rust resist. genes in the wheat line 5R618. Czech J. Genet. Plant Breed. 50: 262-267 
Winzeler M, Mesterházy A, Park R F, Bartos M, Csösz H, Goyeau M, Ittu E, Jones F, Löschenberger K, Manninger M, Pasquini K, Richter D, Rubiales G, Schachermayr A, Strzembicka M, Trottet O, Unger G \& Vida Walther U (2000). Resistance of European winter wheat germplasm to leaf rust. Agronomie 20: 783-792

Xu X, Bai G, Carver B F, Shaner G E, Hunger R M (2005). Molecular characterization of slow leaf-rusting resistance in wheat. Crop Science 45: 758-765

Zaman A U, Khatun T, Hanefi M \& Sahebi M (2017). Genetic analysis of rust resistance genes in global wheat. Cultivars. Agriculture and Environmental Biotechnology pp. 431-445

Zhang H, Xia X C, He Z H, Li X, Li Z F \& Li D Q (2011). Moleculer mapping of leaf rust resistance gene LrBi16 in Chinese wheat cultivar Bimail16. Moleculer Breeding 28: 527-534

Zhou Y, Wu Y, Li X, Li Z F \& Li D Q (2012). Genetic analyses and moleculer mapping of leaf rust genes in two Chinese wheat lines. Scientia Agricultura Sinica 45: 3273-3380

Zhou Y, Xia X C, He Z H, Li X, Li Z F \& Li D Q (2013). Fine mapping of leaf rust resistance gene LrZH84 using expressed sequence tag and sequence-tagged site markers and allelism with other genes on wheat chromosome $1 \mathrm{~B}$. Phytopathology 103: 169-174 